\title{
Impact of Viscosity Variation, and Flow Rate on Coefficient of Discharge in Venturimeter Utilizing Taguchi Methodology
}

\author{
Manoj Modi, Swati D. Chougaonkar, V. Patil, Prachi Kaneherkar, Namrata Chandel, Jayant \\ Awasthi, Kartik Pawar
}

\begin{abstract}
Most of the industries are concerned with flow measurement and accurate measurement of fluid is important to obtain specific proportion as per process requirement. Generally Venturimeter (VM) is utilized in enterprises due to notable highlights offered by it. VM works on the principle of pressure difference i.e. Bernoulli's principle. By varying cross sectional area of flow, it creates pressure difference along its length which is used to calculate theoretical discharge. Head loss in VM is less as compared to other flow measuring apparatus. Because of its specific geometry eddies formation is avoided causing less head loss. The coefficient of discharge $\left(C_{d}\right)$ is an important parameter always referred in case of flow measuring devices. For VM it varies from 0.95 to 0.99 . Tests have been performed in accordance to Taguchi L9 O-A on cast iron pipe to examine the impact of variations of viscosity, and rates of flow on the $C_{d}$.
\end{abstract}

Keywords: Viscosity, flow rate, VM, and Coefficient of Discharge, etc.

\section{INTRODUCTION}

Venturimeter (VM) is an apparatus utilized for estimating the fluid flow rate in a pipe. The working concept of VM is by decreasing the $\mathrm{C} / \mathrm{S}$ area of the fluid-flow of entry, the variation in pressure is made and the estimation of pressure variation empowers us to calculate the release from the pipe. The VM comprises 3 primary components viz. Throat, Converging and Diverging part. Klochko et al. [1] investigated the execution of a VM in fluid-gas stream within the diffuse gases for drop in pressure. Bansode et al. [2] investigated the variability in pressure over the VM utilizing C-FD examination and authenticated the outcomes by

Revised Manuscript Received on April 21, 2020.

* Correspondence Author

Dr. Manoj Modi,*, Department of Mechanical Engineering, Acropolis Institute of Technology, and Research, Indore, India.E-mail: manojmnitjaipur1@gmail.com

Swati D., Chougaonkar ,Department of Mechanical Engineering, SGSITS, Indore, India.

Prachi Kaneherkar, Department of Mechanical Engineering, SATI, Vidisha, India.

V. Patil, Department of Mechanical Engineering, Acropolis Institute of Technology and Research, Indore, India.

Namrata Chandel, Department of Civil Engineering, Acropolis Institute of Technology, and Research, Indore, India.

Jayant Awasthi, Department of Civil Engineering, Acropolis Institute of Technology, and Research, Indore, India.

Kartik Pawar, Department of Mechanical Engineering, Acropolis Institute of Technology and Research, Indore, India.

(C) The Authors. Published by Blue Eyes Intelligence Engineering and Sciences Publication (BEIESP). This is an open access article under the CC BY-NC-ND license (http://creativecommons.org/licenses/by-nc-nd/4.0/) experimental test. San et al. [3] examined the impacts of angles of C-D on $\mathrm{C}_{\mathrm{d}}$ and over-perusing in W-gas stream estimation. This work reported about the $\mathrm{D}$-angles have critical impact on over-perusing while C-angles have compelling impact on $\mathrm{C}_{\mathrm{d}}$. Wang et al. [4] used C-FD system to investigate the correlation between various factors of $\mathrm{VM}$ and suction limit of VI and interpret the various outcomes. Vijay et al. [5] differentiated 4 unique VM Models to investigate about the various input factors and outcomes utilizing C-FDtechnique. Fig. 1 displays the schematic diagram of venturimeter.

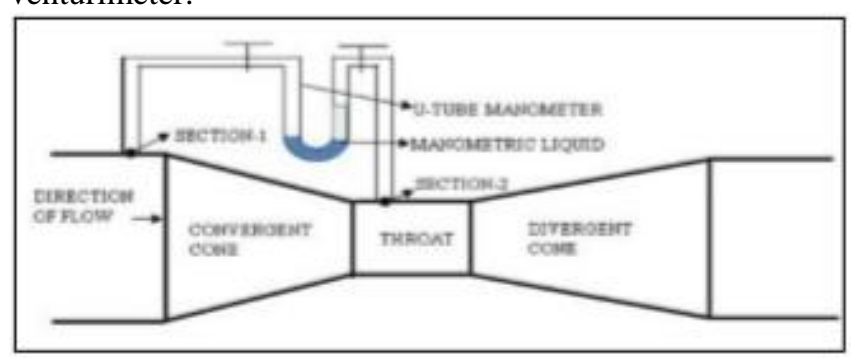

Fig. 1 Schematic diagram of Venturimeter

\section{METHODS TO CALCULATE COFFICIENT OF DISCHARGE}

Adjust the discharge and percentage mixing of glycerin in water and record the difference in pressure ' $\mathrm{h}$ ' to compute the theoretical-discharge $\mathrm{Q}_{\mathrm{th}}$. and evaluate the actual-discharge Qact.

The actual-discharge and theoretical discharge are calculated by the equation 1 , and 2 respectively.

$$
\begin{aligned}
& Q_{a c t}=\text { Volume of fluid/time } \\
& Q_{a c t}=\frac{A_{1} \times A_{2} \sqrt{2 g h}}{\sqrt{\left(A_{1}^{2}-A_{2}^{2}\right)}}
\end{aligned}
$$

The coefficient of discharge is calculated by equation 3 .

$$
C_{d}=Q_{a c t} / Q_{t h}
$$

Where,

A1 - diameter of pipe;

A2 - diameter of throat;

$g=$ acceleration due to gravity; and

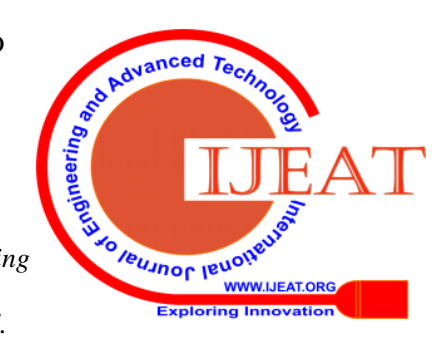


$h$ - difference in pressure head among inlet and the throat.

\section{EXPERIMENTALPROCEDURE WITH FRICTION SET-UP}

One set of nine experiments were conducted in accordance to L9 orthogonal-array on VM set-up. Similarly, various types of Taguchi based O-A has been applied by the various researchers for planning and conduction of experiments in their research works [6-11]. The photographic picture of this frame-up is shown in Fig. 2.

Experiments have been conducted with cast iron pipe to examine the impact of variations of viscosity, and rates of flow on coefficient of discharge in VM set-up. Modi et al. [12, 13, 14] applied Taguchi method in conventional machining procedure for modeling and analyzing the process factors. The level and value of factors associated with these experimental tests are shown in Table 1.

Table 1 Level and value of factors in friction factor determination experiments

\begin{tabular}{|c|l|c|c|c|}
\hline Parameters & Units & Level 1 & Level 2 & Level 3 \\
\hline Glycerin (\% ) & Kg/litre & $\begin{array}{c}0 \\
(0 \%)\end{array}$ & $\begin{array}{c}2 \\
(50 \%)\end{array}$ & $\begin{array}{c}4 \\
(100 \%)\end{array}$ \\
\hline Flow Rate & litre/sec & 0.250 & 0.375 & 0.500 \\
\hline
\end{tabular}

The L9 orthogonal array, experimental plan and outputs for friction factor are portrayed in Table 2.

Table 2 L9 orthogonal array, experimental plan and outputs for friction factor

\begin{tabular}{|c|c|c|c|}
\hline $\begin{array}{c}\text { S. } \\
\text { No. }\end{array}$ & $\begin{array}{c}\text { \% Mixing of } \\
\text { Glycerin }\end{array}$ & $\begin{array}{c}\text { Flow Rate } \\
\text { (litre/sec) }\end{array}$ & $\begin{array}{c}\text { Coefficient of } \\
\text { Discharge }\left(\mathbf{C}_{\mathbf{d}} \mathbf{)}\right.\end{array}$ \\
\hline 1 & 0 & 0.250 & 0.711 \\
\hline 2 & 0 & 0.375 & 0.753 \\
\hline 3 & 0 & 0.500 & 0.812 \\
\hline 4 & 50 & 0.250 & 0.681 \\
\hline 5 & 50 & 0.375 & 0.729 \\
\hline 6 & 50 & 0.500 & 0.763 \\
\hline 7 & 100 & 0.250 & 0.665 \\
\hline 8 & 100 & 0.375 & 0.698 \\
\hline 9 & 100 & 0.500 & 0.741 \\
\hline
\end{tabular}

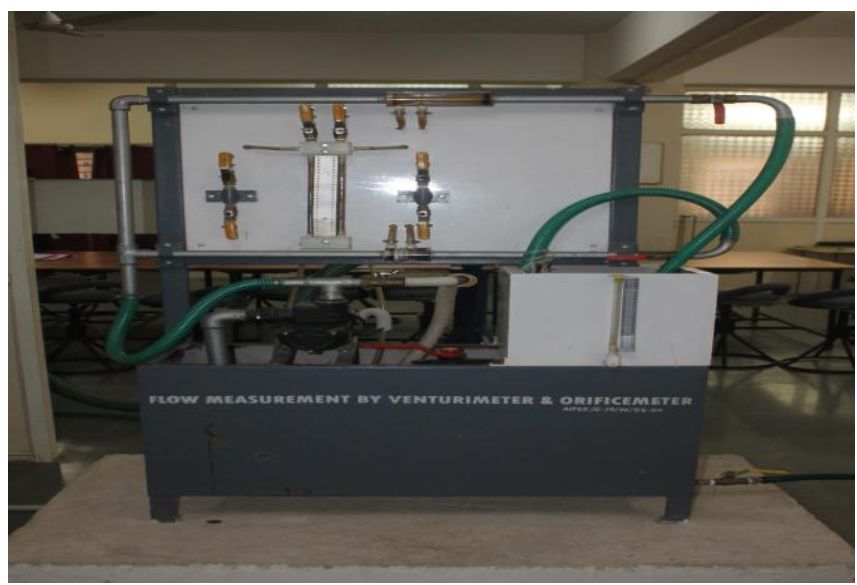

Fig. 2 Experimental Set-Up

\section{RESULTS}

The results obtained show that coefficient of discharge can be mathematically modeled and can be displayed by the Figs. 3, 4, and 5 by MINITAB 17 software.

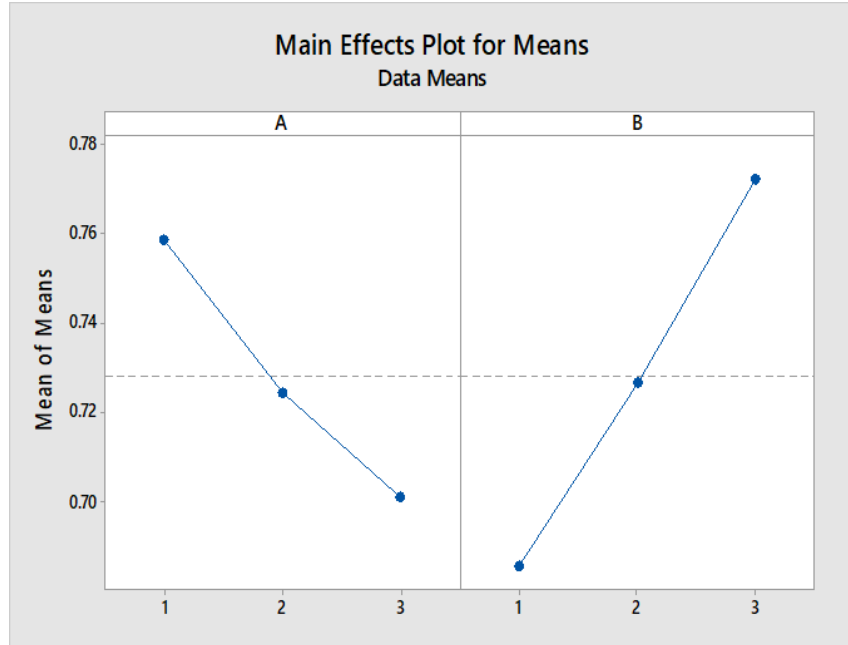

Fig.3 Mean Graph

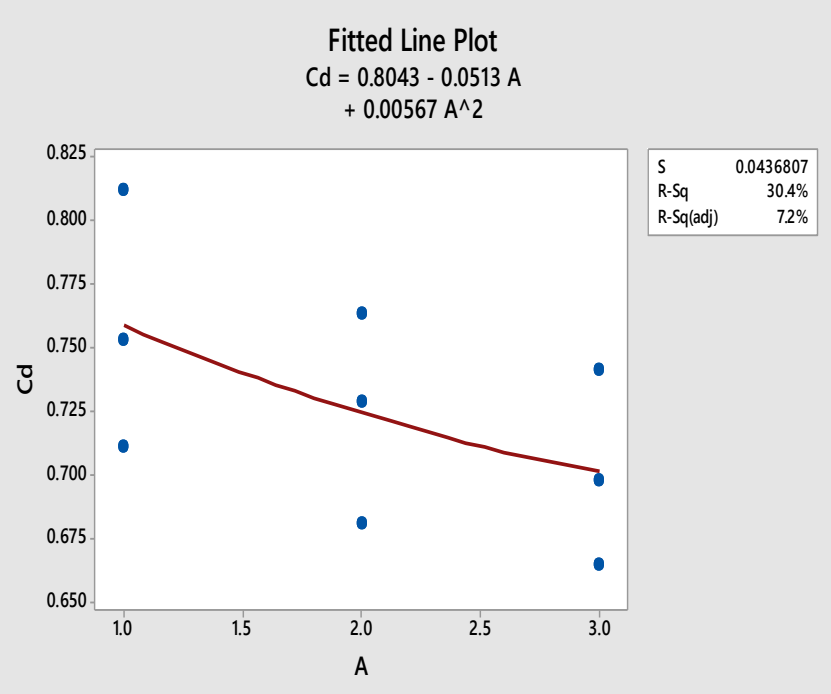

Fig.4 Coefficient of discharge Vs Mixture of water and glycerin

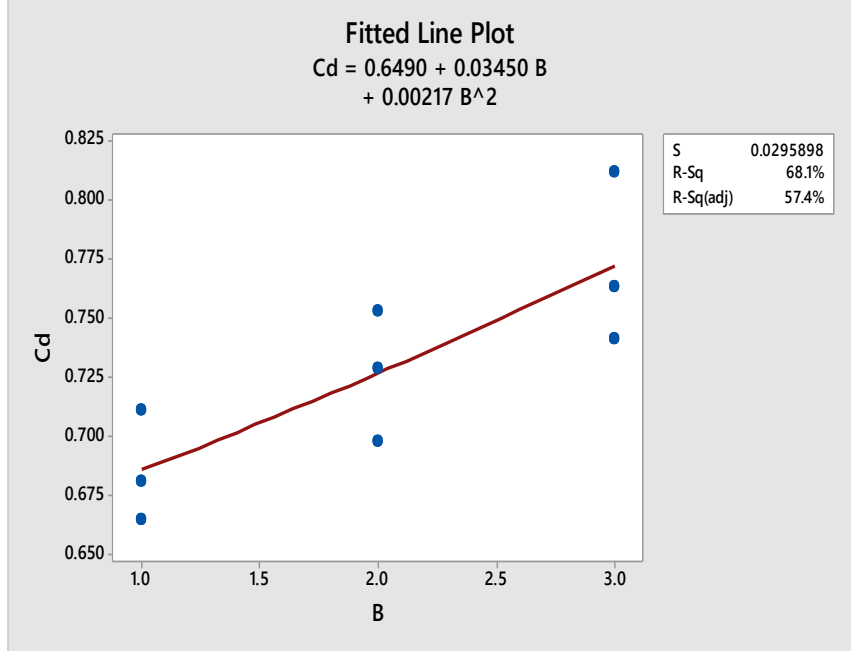

Fig.5 Coefficient of discharge Vs Flow rate

Published By:

Blue Eyes Intelligence Engineering \& Sciences Publication

(c) Convriaht: All riahts reserved.

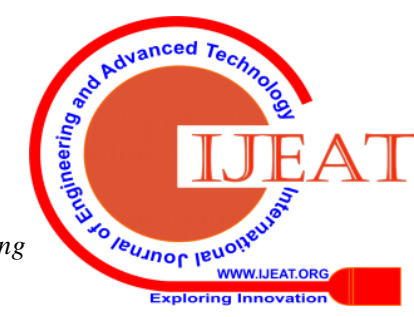




\section{CONCLUSIONS}

The below mentioned outcomes can be drawn dependent on the interpretations from the Figures 3, 4, and 5.

1. The maximum coefficient of discharge is obtained with pure water, followed by 2 liter of glycerin mixed with water, and for 4 liter of glycerin mixed with water produced the minimum coefficient of discharge in this experimental work.

2. The coefficient of discharge is minimum at minimum flow rate, followed by medium flow rate, and maximum flow rate produced the maximum coefficient of discharge.

\section{REFERENCES}

1. T. Elperin, A. Fominykh, M. Klochko. Performance of a Venturi meter in gas-liquid flow in the presence of dissolved gases. Flow Measurement and Instrumentation. 13: (2002), 13-16.

2. N. Tamhankar, A. Pandhare, A. Joglekar, V. Bansode. Experimental and CFD analysis of flow through VM to determine the coefficient of discharge. International Journal of Latest Trends in Engineering and Technology. 3(4): 2014, 194-200.

3. P. Kumar, S. M. San. CFD Study of the Effect of Venturi Convergent and Divergent Angles on Low Pressure Wet Gas Metering. Journal of Applied Sciences. 14(22): 2014, 3036-3045. [4] X. Huang, G. Li, M. Wang. IFIP International Federation for Information Processing, Volume 294, Computer and Computing Technologies in Agriculture II. 2: 2009, 805-815. [5] P. Hari Vijay, V. Subrahmanyam. CFD Simulation on Different Geometries of VM. International Journal of Research in Engineering and Technology. 3(7): 2014, 456-463.

4. Modi, M., Agarwal, G. "Integrated Statistical Methodology for optimizing machining parameters in SiC Powder Mixed - EDDSG process to machine Ti6Al4V", Materiali in Tehnologije / Materials and Technology Journal, Vol. 53 (3), pp. 357-366, 2019, DOI: https://doi.org/10.17222/mit.2018.194

5. Modi, M., Agarwal, G. "Powder Mixed Electro Discharge Diamond Surface Grinding Process: Modelling, Comparative analysis and Multi-output optimization using Weighted Principal Components analysis", SV-Journal of Mechanical Engineering, Vol. 59 (12), pp 735-747, 2013, DOI: https://doi.org/10.5545/sv-jme.2013.1146.

6. Modi, M., Agarwal, G. "Optimization of Electro-Discharge Diamond Surface Grinding Process Parameters with Multiple Performance Characteristics of Ti-6Al-4V using Grey-Taguchi approach", International Journal of Advanced Materials Research, Vols. 622-623, pp. 14-18, 2012,DOI: https://doi.org/10.4028/www.scientific.net/AMR.622-623.14

7. Modi, M., Agarwal, G., Chaugaonkar, S. D. "Grey-WPCA Based parametric-optimization and modelling of chromium Powder Mixed Surface electro Discharge Diamond Grinding of Inconel 600 using RSM", Journal of Mechanical Engineering- Strojnícky časopis, Vol. 69 (4), pp. $65 \quad-\quad 88, \quad 2019$, DOI: https://doi.org/ 10.2478/scjme-2019-0044.

8. Modi, M., Agarwal, G. "Influence of Dielectric Jet flushing during Electro Discharge Diamond Surface Grinding process", International Journal of Advanced Materials Research, Vols. 652-654, pp. 2187-2190,

2013,DOI:

https://doi.org/10.4028/www.scientific.net/AMR.652-654.2187.

9. Modi, M., Jha, S. "Modeling and Analysis of Powder Mixed Electric Discharge Machining", International Journal of Mechanical Engineering, Vol. 2 (2), pp. 219-223, 2009.

10. Modi, M., Agarwal, G., Patil, V., Bhatia, U. \& Pancholi, R. "Parametric optimization in Drilling of $\mathrm{Al} / \mathrm{SiC}$ composite using Taguchi Method", International Journal of Scientific \& Technology Research, Vol. 8 (9): 2019-22, 2019.

11. Modi, M., Agarwal, G., Patil, V., Khare, A., Shukla, S. \& Shankhla, A. "Modeling and Analysis of Turning Process on Lathe Machine by Taguchi and ANOVA Approach", International Journal of Scientific \& Technology Research, Vol. 8 (10): 1466-70, 2019.

12. Modi, M., Patil, V., Chougaonkar, S.D., Kaneherkar, P., Chandel, N., Sharma, Y. "Influence of viscosity variation on coefficient of friction in pipe flow with different pipe materials and flow rates using Taguchi Design Method", International Journal of Engineering and Advanced Technology, Vol. 9 (4), 2020.

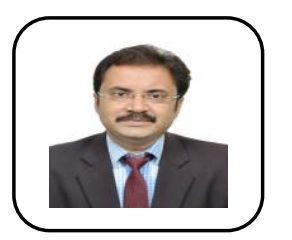

\section{AUTHORS PROFILE}

Dr. Manoj Modi received his Ph.D. from MNIT Jaipur, India. He is currently working as a Professor in Mechanical Engineering Department in AITR, Indore, India. His research interests include advanced machining process, Hybrid Machining Process, Thermal Engineering, and FM etc.

Mr. Veerandra Patil is working as an Assistan Professor in the Department of Mechanical Engineering, Acropolis Institute of Technology \& Research, Indore, India. He received my M.E. from Govt. Engineering College Ujjain, RGPV Bhopal MP. He has published three papers in International Journals. My areas of specialization are Industrial Engineering \& Management, Production Engineering etc.

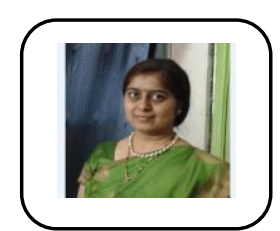

Ms. Swati D Chougaonkar is working as an Associate Professor in Mechanical Engineering Department of SGSITS Indore. She has 16 years of teaching experience in this institute. She has done her B.E. from MITS, Gwalior and M. Tech. in Thermal Engineering from MANIT, Bhopal. Her areas of research interest are: HMT, RAC, Production and Components used in Power Plant.

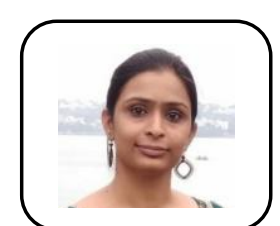

Ms. Prachi Kanherkar has done her M.E.in 2011 from S.G.S.I.T.S. Indore, India. She is currently working as an assistant professor in Mechanical Engineering Department in S.A.T.I. Vidisha, India. Her Area of interest including computer integrated manufacturing, casting, designing, production engineering, Thermal Engineering, and solar energy.

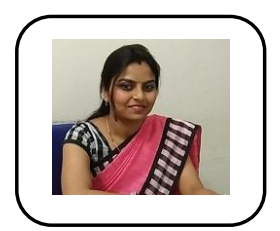

Ms. Namrata Chandel is pursuing the Ph. D. from SVNIT Surat. She is currently working as an Asst Professor in Civil Engineering Department in Acropolis Institute of Technology \& Research Indore, India. Her research interests include Water Resources Engineering, Fluid Mechanics, and Hydraulic structures etc.
Published By:

Blue Eyes Intelligence Engineering \& Sciences Publication

(C) Copyright: All rights reserved.

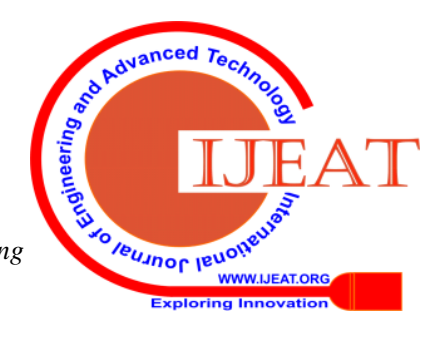

